\title{
Teaching Across Disciplines: The Christmas Bell
}

Virginia Anne Taylor, (Email: TaylorV@wpunj.edu), William Paterson University

\begin{abstract}
The primary focus of this teaching case is a demonstration of the interdisciplinary nature of business production decisions. The issues involved show students how to think outside the single function box of management and consider accounting, finance, and economics.
\end{abstract}

\section{INTRODUCTION}

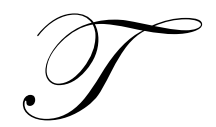

he complicated nature of worldwide business transactions makes analytical decision support models absolutely essential to allow increasingly powerful information technology to process the enormous volume of data generated by global operations. Due to the complexity of today's work world, traditional theories from the management or economics discipline may prove individually inadequate as the basis for executive decisions. Since this is the work environment our students will face, it is essential to provide them with opportunities to think across disciplines in a meaningful way. The specific objectives of this paper are to help students identify the underlying reasons for multinational enterprises'production decisions and to develop an interdisciplinary model to analyze how these decisions might occur. The challenge is to use existing theoretical lenses to examine the phenomenon and thereby gain better understanding of their uses and limitations. An overview of the literature indicates accounting and management studies draw support from economics and finance theory. This paper ties the strands together for an overview using a short teaching case to look at economic factor endowments and public policy considerations. It serves as a learning bridge illustrating how theories from various business disciplines fit together to provide analytical decision support.

\section{The Christmas Bell}

This model product, a silver bell, is produced for sale at high end retail stores in New York City. Its full retail price is $\$ 79.95$ and it is especially popular during the Christmas shopping season in the USA. Our specialty gift manufacturer has some choices. Production can be scheduled at any time of year in the USA or China. We assume the owner wants to realize as much after-tax profit as possible.

In this teaching example, we will assume the primary production costs, Direct Materials, Direct Labor, and Factory Overhead are different for each of the production locations that are currently under consideration. For simplicity we will focus on the main "Direct Material" cost determinant, which is the local price of the sterling silver, the primary raw material component of the bell. In Figure I, the direct materials dollar amount represents the necessary amount of raw materials silver per unit of production. Direct labor cost includes the salary and benefits costs for workers on the production line. Factory overhead amount represents the traditional costs of factory supervision, rent, and maintenance. In New York City selling expenses incurred at the store level would include retail overhead, store profit margin and commission. Although important to overall gross margin, they are not really relevant to the production decision because they do not change with the production location. At the time this paper was written the Yuan foreign exchange rate per US Dollar was approximately 8.08 Yuan per dollar as quoted in USA Today, 11/15/05. This example rounded down. 
Figure I - Current Exchange Rate

\begin{tabular}{|lccc|}
\hline & USA & China & Yuan \\
Direct Materials & $\$ 10$ & $\$ 10$ & 80 \\
Direct Labor & $\$ 10$ & $\$ 2$ & 16 \\
Factory Overhead & $\$ 5$ & $\$ 2$ & 16 \\
Total Manufacturing Cost & $\$ 25$ & $\$ 14$ & 112 \\
Shipping Cost & - & $\$ 2$ & \\
Selling Expense & $\$ 10$ & $\$ 10$ & \\
Total Cost & $\$ 35$ & $\$ 27$ & \\
\hline
\end{tabular}

In the example above the current price of local silver, the main production material is approximately the same in China or the USA. In other words the per-unit cost for silver is $\$ 10$ US or about 80 Yuan. However, because wages and the cost of living are much lower in China, the per unit factory direct labor cost is significantly lower in China. In addition the Chinese production also incurs transportation or shipping cost that is not required for US production. As the example below indicates, the total production cost is $56 \%$ higher in the USA and even after adding shipping and selling costs, the total cost in the USA is still $30 \%$ higher. Assuming a selling price of $\$ 80$, the US production unit nets a before tax profit of only $\$ 35$ per unit versus $\$ 53$ per unit for the Chinese production units. This $\$ 18$ difference can have many effects. For example, The bells produced in China could be sold at a $20 \%$ price reduction and still generate a higher per unit profit than US produced units.

\section{CHANGES IN THE FOREIGN EXCHANGE RATE}

Finance issues and foreign exchange rates can greatly influence the production decision. Today, the US Dollar buys a lot of Chinese Yuan. However, some US citizens and congressmen believe the Chinese government has deliberately held down the true value of the Yuan in order to make Chinese goods cheaper and more attractive in the US market. One result has been a soaring trade deficit with China. Many politicians, manufacturers and everyday citizens want steps taken to lower our trade deficit with China. Some have tried to pressure the Chinese government to raise the value of the Yuan by as much as 50\%. They feel this would help level the playing field, save jobs, and remedy the USA's trade deficit.

In the above example the price of local silver was been converted into US\$ at the rounded current exchange rate of eight Chinese Yuan to one US dollar. In other words, today, one unit of direct materials purchased in China costs 80 yuan. At the current exchange rate that equals ten US dollars. Now we will look at how changes in the foreign exchange rate would influence the relative production cost using different foreign exchange rate scenarios and holding all other things constant. First, consider what happens when the exchange rate or value of the Chinese Yuan rises or falls in relation to the US Dollar. Suppose the Chinese government allows the value of the Yuan to raise by $50 \%$, each US dollar will be worth $50 \%$ less. Since each dollar would buy only 4 yuan, the direct materials silver will now cost twenty US dollars. The firm will also spend more dollars to pay for Chinese labor and factory overhead. In this scenario, the Chinese production cost now totals $\$ 28$, which is more expensive than US production. The firm will keep production in the USA because the total US cost, $\$ 35$, is lower and shipping expenses are avoided. As Figure 2 indicates, the foreign exchange rate or the relative value of the Chinese Yuan affects the production cost and decision. It compares production cost under three possible exchange rates: today's value with a ratio of $8 \mathrm{Y} / \$$. Higher Yuan value when ratio of $4 \mathrm{Y} / \$$ results, or Lower Yuan if the Chinese government lowers the value of the Yuan by 50\% and a ratio of $12 \mathrm{Y} / \$$ results. 
Figure 2 - Chinese Silver

\begin{tabular}{|c|c|c|c|c|}
\hline & USA & China Now @8 & High@4 & Low@12 \\
\hline Direct Materials & $\$ 10$ & $80 \mathrm{Y}=\$ 10$ & $\$ 20$ & $\$ 6.67$ \\
\hline Direct Labor & $\$ 10$ & $16 Y=\$ 2$ & $\$ 4$ & $\$ 1.67$ \\
\hline Factory Overhead & $\$ 5$ & $16 Y=\$ 2$ & $\$ 4$ & $\$ 1.67$ \\
\hline Total Manufacturing Cost & $\$ 25$ & $112 Y=\$ 14$ & $\$ 28$ & $\$ 10$ \\
\hline Shipping Cost & - & $\$ 2$ & & \\
\hline Selling Expense & $\$ 10$ & $\$ 10$ & & \\
\hline Total Cost & $\$ 35$ & $\$ 27$ & $\$ 40$ & $\$ 22$ \\
\hline
\end{tabular}

\section{TRADE \& FOREIGN DIRECT INVESTMENT}

This firm is producing goods for export to the USA, the Chinese government is happy to have them build or rent factory space and create jobs for Chinese workers. However if the firm also wanted to sell some Christmas Bells within China, they would probably face very strict local content regulation. This means they would be required to use local raw materials whenever possible. In the past some firms have been forced to invest significant sums on local infrastructure or research facilities before the government would allow them into China. Therefore in the "High@4 scenario in Figure 2 we assumed the silver was a local purchase in China for 80Yuan and therefore it would cost more US dollars to buy the same amount when the Yuan appreciated.

Now suppose we could purchase the silver in the open world market where it is priced in US \$. Then in the high yen scenario, the per-unit direct materials cost would go down because each Yuan bought more silver. You would only spend $40 \mathrm{Y}$ to buy $\$ 10$ worth of world market silver. The resulting Chinese production cost would drop to $\$ 18$ because only the local labor and factory overhead would be increased due to the higher yuan/lower dollar foreign exchange rate. On the other hand, if it takes twelve Yuan to buy $\$ 10$ worth of silver the raw material coast would soar to 120 yuan; but the cheaper local labor and factory overhead costs make this cheaper than production in the USA.

Figure 3 - World Market Silver

\begin{tabular}{|lcccc|}
\hline & USA & China- Now @8 & High@4 & Low@12 \\
Direct Materials & $\$ 10$ & $80 \mathrm{Y}=\$ 10$ & $\mathrm{Y} 40=\$ 10$ & $\mathrm{Y} 120=\$ 10$ \\
Direct Labor & $\$ 10$ & $16 \mathrm{Y}=\$ 2$ & $\mathrm{Y} 16=\$ 4$ & $\mathrm{Y} 16=\$ 1.67$ \\
Factory Overhead & $\$ 5$ & $16 \mathrm{Y}=\$ 2$ & $\mathrm{Y} 16=\$ 4$ & $\mathrm{Y} 16=\$ 1.67$ \\
Manufacturing Cost & $\$ 25$ & $112 \mathrm{Y}=\$ 14$ & $\mathrm{Y} 72=\$ 18$ & $\mathrm{Y} 152=12.67$ \\
Shipping Cost & - & $\$ 2$ & $\$ 2$ & $\$ 2$ \\
Selling Expense & $\$ 10$ & $\$ 10$ & $\$ 10$ & $\$ 10$ \\
Total Cost & $\$ 35$ & $\$ 30$ & $\$ 24.67$ \\
\hline
\end{tabular}

\section{TAXES, TARIFFS \& TRADE RESTRICTIONS}

These tables did not consider the effects of taxes, tariffs and other trade restrictions. Corporate income tax rates differ around the world, but always reduce profits. This case could be expanded to examine alternate profit recognition examples. If enough congressmen decide the trade deficit with China is troublesome and negatively affecting the labor market in their district, we could see a tariff imposed. It would be set high enough to offset the price advantage of cheap labor and production costs in China. This would mean higher prices for the American customers but would make certain labor unions happy as it might save some American jobs. Even though the net result is negative because consumers lose than the workers gain, it is more acceptable than alternate economic policy 
solutions. Restrictions such as dumping duties and voluntary price restrictions benefit the competitors or foreign governments and do not contribute anything to our domestic welfare. Probably congressional votes for tariffs and other trade restrictions will depend on the relative union support within the individual home districts

\section{SUMMARY}

Profit is the star of any management discussion; companies are in business to make profits. In fact it is their economic reason to exist. Today, the global nature of economic business activity makes understanding of the impact of foreign exchange rate volatility an important management skill. All management and marketing students would benefit from the integration of this accounting and/or finance topic into their decisions. Tax rates, foreign direct investment incentives, trade tariffs, restrictions, and impediments must be considered when making worldwide production decisions.

\section{Figure 4 - The Profit Star}

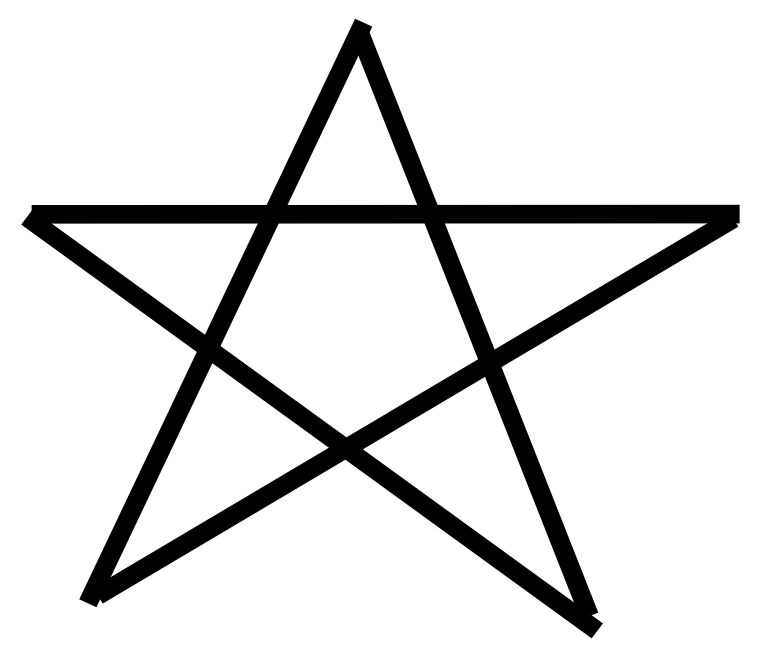

